\title{
Prof. JUDr. Karel Malý, DrSc., dr. h. c. oslavil 26. října minulého roku 90. narozeniny
}

Profesor Karel Malý se narodil 26. října 1930 v Mnichově Hradišti, avšak téměř celý svůj život prožil v Praze, kam se s rodiči v roce 1932 přestěhoval. Po absolvování reálného gymnázia ve Vysočanech studoval na Právnické fakultě Univerzity Karlovy v Praze, kterou ukončil v roce 1954. A právě s Právnickou fakultou a Univerzitou Karlovou je spojena jeho dlouhodobá profesní kariéra.

Již během studií se projevil jeho zájem o právní dějiny, nebot' na katedře dějin státu a práva Právnické fakulty Univerzity Karlovy začal své působení jako pomocná vědecká síla. Poté na katedru nastoupil v roce 1954 jako asistent, od roku 1957 zde pracoval jako odborný asistent, následně jako docent (od 1965) a posléze jako profesor právních dějin (1990-2015). Právním dějinám, zejména právním dějinám českým a československým pak zůstal pedagogicky a badatelsky trvale věrný a právem patří mezi nejvýznamnější české právní historiky druhé poloviny 20. století.

V roce 1960 obhájil kandidátskou disertaci a v roce 1965 získal vědeckou hodnost doktor věd, a to rozhodnutím prezídia Československé akademie věd po úspěšně obhájené doktorské disertační práci Trestní právo v Čechách v 15.-16. století. Na Právnické fakultě Univerzity Karlovy v Praze vedl v letech 1990 až 2010 Ústav právních dějin a od roku 2007 do roku 2015 i Centrum právněhistorických studií, společné pracoviště PF UK a Historického ústavu AV ČR. V letech 1998-2005 byl zároveň vedoucím katedry právních dějin.

Profesor Malý se zároveň podílel na obnově univerzitní akademické samosprávy. V letech 1991-1994 byl prorektorem a v letech 1994-2000 rektorem Univerzity Karlovy v Praze. Podařilo se mu uskutečnit vnitřní evaluaci univerzity a z ní vyplývající změny s cílem zajistit kvalitu vědecké a pedagogické práce a přizpůsobit univerzitu vysokým nárokům současnosti. $V$ průběhu jeho druhého volebního období úspěšně proběhly oslavy 650. výročí založení Univerzity Karlovy, ke kterému univerzita uspořádala velké množství vědeckých konferencí a setkání, a jež napomohly ukázat, že Univerzita Karlova je skutečným centrem vědy a vzdělávání nejen v České republice. Jeho činnost byla oceněna zlatou medailí a minulý rok i historickou medailí Univerzity Karlovy i medailí Právnické fakulty.

Profesor Malý byl dlouholetým členem vědecké rady Právnické fakulty Univerzity Karlovy a členem vědecké rady Univerzity Karlovy v Praze, v současnosti je čestným členem těchto vědeckých rad. Je nositelem medaile I. stupně ministra školství, mládeže a tělovýchovy, jubilejní medaile Univerzity Karlovy a zlaté Randovy medaile. V roce 1997 byl vyznamenán zlatou medailí za zásluhy o Rakouskou republiku a v témže roce mu byl udělen čestný doktorát práv na Trinity College v Dublinu a v roce 1998 na Komenského 
univerzitě v Bratislavě. V roce 1999 mu bylo papežem propůjčeno vyznamenání za zásluhy o víru a církev.

Zvláště bych však rád vyzvedl jeho zásluhy o Právněhistorické studie, které na počátku 90. let převedením na naši univerzitu a do jejího nakladatelství bezesporu zachránil jako unikátní periodikum pro oblast právních dějin. Od roku 1990 do 2017 byl předsedou redakční rady časopisu Právněhistorických studií a do současnosti je členem redakční rady.

Profesor Malý je oblíbeným učitelem již několika generací právníků a historiků. Přednášel nejen na Právnické, ale i na Filozofické fakultě UK, a také vystoupil na zahraničních univerzitách v Krakově, Regensburgu, Würzburgu, Augsburgu, Moskvě či Ljubljani, a na velkém množství mezinárodních konferencí. Velké mezinárodní konference také sám pořádal. Byl hlavním řešitelem několika zásadních projektů GA ČR věnovaných jak tradicím českého ústavního práva, tak i československým právním dějinám v první polovině 20. století („Vývoj práva v Československu v letech 1945-1990“, „Vývoj české ústavnosti v letech 1618-1918“, „Československé právo a právní věda v meziválečném období“, „Práva městská království českého“). Organizačně se podílel na mnoha významných konferencích s evropským přesahem. Do současnosti vystupuje na konferencích a seminárích pořádaných tuzemskými odbornými institucemi.

Profesor Malý je také respektovaným autorem nebo spoluautorem mnoha odborných článků a statí, řady monografií a učebnic. Stal se díky nim respektovanou osobností nejen v českém, ale i mezinárodním kontextu. Právě jeho kontakty pomohly české právní historii po roce 1989 rychle nalézt odpovídající místo ve středoevropském právněhistorickém badatelském kontextu. Jeho práce se pravidelně těší příznivému přijetí nejen mezi právními historiky, ale i v širší právnické a historické obci.

Již od studií se badatelsky zaměřil na období stavovského státu a zejména trestní právo tohoto období. Jeho první vědecká studie se zabývala Svatováclavskou smlouvou, následovala řada dílčích studií věnovaných vývoji trestního práva završených v roce 1979 monografií Trestní právo v Čechách v 15. a 16. století, kterou doplnil a přepracoval v roce 1989 v druhém vydání. Trestnímu právu se věnoval i v souvislosti s osvícenskými kodifikacemi, se zemským soudem, s Vladislavským zemským zřízením, Koldínovou kodifikací městského práva. Ta poté za jeho vedení znovu vyšla jako moderní edice doplněná studiemi, které byly výsledkem úspěšného grantu podpořeného GA ČR.

Druhou oblastí badatelského zájmu profesora Malého je období druhé poloviny 19. století a vývoj rakouského práva, vývoj českého politického a státního myšlení a také vývoj státní správy a samosprávy. Jako ředitel Ústavu právních dějin byl také hlavním řešitelem několika velkých projektů s mezinárodní účastí věnovaných jak tradicím českého ústavního práva, tak i československým právním dějinám a dějinám právní vědy za první republiky i po druhé světové válce. $Z$ nich pak vyšly hodnotné výstupy monografického charakteru. I všechny jeho ostatní studie k dílčím tématům, jako například k vývoji jazykového práva či problematice státního občanství, se vyznačují vysokou erudicí a originálním př́istupem. Profesor Malý byl též vedoucím autorského kolektivu publikace Historické impulzy rozvoje práva - I. svazku z pětisvazkové vědecké monografie „Nové jevy v právu na počátku 21. století“, výstupu mezinárodní konference pořádané PF UK v dubnu roku 2008 u př́ležitosti 660. výročí založení Univerzity Karlovy v Praze v rámci výzkumného záměru fakulty a výstupu konference „200 let Všeobecného občanského zákoníku“. 
Jeho učební texty, zejména Dějiny českého a československého práva do roku 1945 (4. vydání, Praha: Leges, 2010), se využívají ve výuce na právnických fakultách dodnes. Věnoval se i popularizaci oboru, zejména v publikaci České právo v minulosti z roku 1995. Ta vhodně ukázala krásu oboru širší čtenářské obci. V roce 2010 byl proto prof. Malý právem uveden do právnické síně slávy v rámci vyhlášení Právníka roku.

Závěrem bych rád připojil o jubilantovi i několik osobně laděných slov. Setkal jsem se s ním již v době svých studií a konal u něj jednu z prvních zkoušek právě z domácích právních dějin. Jeho přednášky a jeho osobnost mě přiměly přemýšlet nad právní historií a zejména nad orientací na české a československé právní dějiny, i když mě nejprve lákaly spíše dějiny anglické. Měl jsem zároveň čest s ním úzce spolupracovat jak v době, kdy prof. Malý stál jako rektor v čele naší univerzity, tak později, kdy řídil katedru a Ústav právních dějin Právnické fakulty. Jsem zejména rád, že jsem mohl na jeho působení na katedře, ústavu i v redakci Právněhistorických studií navázat, a doufám, že i některé jeho myšlenky a projekty dále rozvíjet.

Vždy jsem si na profesoru Karlu Malém cenil jeho př́stupu ke studentům a jeho vztahu k univerzitě, na které, jak již bylo uvedeno, prožil velkou část života a pro kterou toho mnoho udělal. Jako děkan Právnické fakulty UK bych za to profesoru Malému i touto cestou rád poděkoval a zároveň mu popřál do dalších let hlavně hodně zdraví a úspěchů v osobním životě. Ad multos annos pane profesore.

Jan Kuklik

doi: 10.14712/2464689X.2021.8 